\title{
Confronting Denials of Casteism
}

An Interview with Prof. Meena Dhanda, a UK-Based Anti-caste Academic Activist

Nicolas Jaoul and Meena Dhanda

\section{OpenEdition}

\section{Journals}

\section{Electronic version}

URL: https://journals.openedition.org/samaj/7610

DOI: $10.4000 /$ samaj.7610

ISSN: $1960-6060$

Publisher

Association pour la recherche sur l'Asie du Sud (ARAS)

\section{Electronic reference}

Nicolas Jaoul and Meena Dhanda, "Confronting Denials of Casteism", South Asia Multidisciplinary

Academic Journal [Online], 27 | 2021, Online since 26 October 2021, connection on 15 March 2022.

URL: http://journals.openedition.org/samaj/7610 ; DOI: https://doi.org/10.4000/samaj.7610

This text was automatically generated on 15 March 2022.

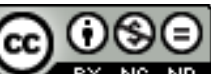

This work is licensed under a Creative Commons Attribution-NonCommercial-NoDerivatives 4.0 International License. 


\title{
Confronting Denials of Casteism
}

\author{
An Interview with Prof. Meena Dhanda, a UK-Based Anti-caste Academic \\ Activist
}

Nicolas Jaoul and Meena Dhanda

\section{Introduction}

Punjab-born Meena Dhanda moved to the UK in 1987 as a Commonwealth Scholar in Philosophy at the University of Oxford. There she became a researcher specializing on caste among Punjabi youth both in the UK and Punjab (Dhanda 1993; Dhanda 2009). In 1992, she started teaching Philosophy and Cultural Politics at the University of Wolverhampton, a city with a large concentration of Punjabi-speaking people of Indian origin (2011 census). She has since published several articles on caste in the UK (Dhanda 2020, 2017, 2014) and has become one of the important voices in the debates on the prevalence of casteism in the UK. She joined the UK anticaste movement in 2008. In 2013, she was appointed Principal Investigator [PI] of a research project on "Caste in Britain" funded by the UK Equality and Human Rights Commission. She has also regularly appeared in British media, as featured in the documentary Caste Aside (Mogul 2017) and was the sole consultant for a BBC1 documentary: Hindus: Do we have a caste problem? (Qayum 2019), which has been viewed by over 1 million people.

She talked about her anti-caste activism experience in the UK with Nicolas Jaoul, a French anthropologist who has specialized on the Ambedkarite movement in India and worked on its British counterpart as well (Jaoul 2006, and in this special issue).

NICOLAS JAOUL (NJ): Let me first ask you to introduce some elements of your biography and socio-cultural background and tell us under what circumstances you settled in the UK.

Meena Dhanda (MD): I grew up in Ludhiana, Indian Punjab, in a prominent business family that had seen very good days-my father travelled widely for the hosiery export business-but in the early-70s was hit by decline. My grandfather Padam Das Dhanda was the first to register a telephone in the city (with the number "only 2") and his cousin Hans Raj Dhanda was a pioneer of Ludhiana hosiery dating back to 
1932. I went to a Catholic convent English-medium school, excelled in my studies and recall growing up with a strong resolve to be an independent professional and not to follow the family tradition of marrying into another business family. I almost had contempt for businessmen, largely due to their patriarchal attitudes. The main influences for acquiring a sense of gender equality were my mother's independent attitude attributable to her upbringing in cosmopolitan Bombay and my father's open-mindedness due to international travel. I hated the thought that my parents may have to save for a dowry, which a businessman would have expected. So, with a view to become an independent woman, I studied the sciences in higher secondary, and Economics and Mathematics as an undergraduate and then, partly to leave Ludhiana, for my masters I chose to study Philosophy, which was not taught in my hometown. It was a financial burden for my father but he agreed to fund my postgraduate education and thus I arrived at Punjab University (PU), Chandigarh. That opened a door for me. A year and a half after joining PU, in the course of my masters' degree (1980-82), I had a cross-caste, cross-religious marriage with a Sikh Marxist university lecturer in Economics, against the wishes of my largely Hindu family; a year later I had my daughter. My mother was a Radhasoami (of the Dayalbagh branch in UP) ${ }^{1}$ who initially objected to my marrying a meat-eating, alcohol-consuming non-Radhasoami. I was shocked when my father asked about my prospective husband's caste. On learning he was a Jat, his retort was, "but Jats are Sudras." But within weeks of my marriage, when their Radhasoami guru M.B. Lal gave his blessings, so did my parents, thereafter accepting my marriage unreservedly. Throughout this tumultuous period, I had become active in campus politics through a student group we helped to organize in 1980 called the Democratic Students Forum (DSF), which contested student elections and won an important post in 1980, upsetting the hegemony of established parties. DSF was broadly an independent leftist grouping. Many of us have practiced in our professional lives the values we espoused as students. As seemed to be the case in left groups at the time, we did not discuss caste, and in hindsight that was reflective of our caste privilege. ${ }^{2}$ I campaigned for the rights of women hostellers at PU. Campaigning taught me a lot about politics, but nothing about caste at that point. An eye-opener for me was the first visit in 1982 to my Jat husband's village, where a street divided the poor landless "majhbi" (Dalit) households from Jat households, although both groups were Sikhs. My husband's Marxism may have relaxed his interactions with the "siris" (the landless laborers contractually employed on his family farm) but the caste-based spatial distancing was starkly there. This discrepancy was disturbing for my naïve political expectation that his ideological values should have had an impact on his family's lived relations rather more than they had done. This was the period of militancy in Punjab, followed by the horrendous anti-Sikh violence of 1984 . Personally, it was a very difficult period, as a majority of my relatives on my father's side were practicing Hindus, my mother's side were Radhasoamis, and from my husband's side there were Sikhs: there were endless intense arguments on the political situation amongst members of the extended family. Fear and tension were at a peak. In 1985, I passed the national exam for a UGC (University Grants Commission) Junior Research Fellowship in Philosophy and when the opportunity arose, I applied for and was awarded a Commonwealth Scholarship to pursue my doctoral studies (DPhil) in Philosophy at Oxford University on the subject of "The Negotiation of Personal Identity," published a few years later. (Dhanda 2008) I wanted to eventually 
figure out the deficiencies of mainstream Anglo-American political philosophy (e.g. in Charles Taylor's writings) when applied to understanding the identity of the Untouchable becoming a Dalit. That brought me to the UK in 1987, and my young family came with me.

NJ: What made you interested in this issue of untouchability and the Dalit movement while still in India? Did you know about the Backward and Minority Castes Employees Federation (BAMCEF), the Dalit Soshit Samaj Sangharsh Samiti (DSSSS or DS4) and the Bahujan Samaj Party (BSP), which were active in Punjab?

MD: My parents were Congress voters and my husband's family were supporters of the Shiromani Akali Dal founded in 1920, the largest Sikh political party worldwide. Whilst in India the question of Untouchability and Dalit identity was mainly theoretical for me-a puzzle in political philosophy. I did not know about BAMCEF, DS4 or BSP. My Marxist husband, who was the president of the Punjab University teachers' union, rarely discussed caste politics. After starting my DPhil research, I began reading more about the condition of Untouchability. Barbara Joshi's edited collection Untouchable: Voices of the Dalit Liberation Movement (Joshi 1986) was one of the first books on caste I read in the UK. I read about Ambedkar, not his own writings, which I discovered much later, though I had occasion to interact with Valerian Rodrigues who was also in Oxford at the time working on Ambedkar. My first theoretical reflections on Untouchability and the limitations of Western political philosophy in understanding it were published in a French journal article (Dhanda 1993).

NJ: In a previous interview, you explained that your ongoing advocacy against caste in the UK reflected your immediate family's commitment to a culture of equality, which stood in contradiction to the persistence of caste and untouchability in Punjab and in Punjabi communities in the UK. Could you summarize your personal evolution regarding caste and explain how your understanding of it evolved after you settled in Wolverhampton?

MD: Contradictory attitudes to caste are inescapable in the lives of privileged caste groups. My situation was not an exception. We grew up in a caste-infused environment, yet we were seemingly oblivious to it. The Radhasoami faith of my parents was anti-casteist in the sense that the caste of the followers was not mentioned or used within the Satsang (literally: the fellowship of the true) in any identificatory way. My mother's family name was "Satsangi." As a matter of fact, in my immediate family from my mother's side, there are three very close relatives with marriages across the Dalit/non-Dalit border. Juergensmeyer (1991) highlights the Radhasoami egalitarian "spirit of defying caste." I have confessed to my own "purity" concerns as a child, even as I broke caste taboos (Dhanda 1993). Ironically, it was our Sikh neighbor who once asked my mother why she allowed Shakuntala, employed as a cleaner, to knead the dough. To this reminder, my mother responded emphatically that she does not recognize any castes or untouchability. Yet, the privilege of caste found assertion in our lives, not just in a taken-for-granted way, but overtly too. My brothers' friends routinely referred to each other by their caste names-Brar, Dhanda, Gupta, Sood, Sharma, Siddhu, Mittal (all savarna/upper castes), rather than their first names. I did not make anything of it at the time, but now note the deeply embedded caste identifications amongst the elite of Ludhiana. After studying in Oxford, I came as a lecturer in philosophy to Wolverhampton in 1992 and for several years was a commuter between Oxford and Wolverhampton, focused on teaching mainstream philosophy, with little socialization with South Asian communities. My 
doctoral research was on hold for a long time. Gradually, when I settled in Wolverhampton, I learnt about my students' experience of caste prejudice. This was totally unexpected. I completed my DPhil in 2004, and shortly afterwards I got a book grant to support a pilot project on "negotiating Dalit identity," which I used to educate myself more generally about caste from a sociological, anthropological and historical point of view. I had been puzzled by the question of why caste persisted in the diaspora when there did not seem to be any external exigencies requiring its continuation.

NJ: In a previous article (Dhanda 2009) on Dalit Punjabi youth in the UK and in Punjab, you show that it can be more difficult for youngsters to escape certain constraints of caste sociability in the UK as compared with India. Would you say that Punjabi migrants in the UK developed a specific caste consciousness?

MD: I did this pilot project comparing young British Dalit Punjabis' experience of caste in Wolverhampton in 2007 with young Dalit Punjabis' experience of caste in Punjab. I recorded video interviews with Dalit students at Boota Mandi (Jalandhar), Engineering College (Chandigarh), Government College (Ludhiana) and in Wolverhampton. I also video-interviewed key informants like Professor Sukhadeo and Vimal Thorat, Surinder Jodhka and Satya Pal Gautam (my late philosophy teacher, then a Professor at JNU). I found enthusiasm for professional advancement amongst the Dalit youth in Punjab, and a complex attitude to caste-based reservations. Some suggested they had not needed to use it, but others suggested that reservation ought to be extended to the private sector too. Their concerns seemed to be job-related. In Wolverhampton a few hidden stories emerged of caste bordercrossings in marriage. UK students also reported caste-related bullying experienced as school children. I did not expect endogamy to be as prevalent in the UK as I found in Punjab (Dhanda 2012). I presented my pilot research with video clippings to CasteWatch UK (Annual conference 2008). There I met Dalit activists who were trying to get caste included in the Equality Act and began to engage a little more beyond academic environments with the local community, but mainly through visits to Dalit places of worship (Ravidassia temples, Buddha Viharas, Valmiki temples).

This research was followed by a larger comparative project Caste Aside: Dalit Punjabi Identity and Experience (2010-12). Then out of the blue, something lifechanging happened. I received an email on June 21, 2011 opening with the words: "Let me introduce myself. My name as you will see from my email id is A. Matharu." $\mathrm{He}$ described himself as a "British Punjabi man in despair" who had "stumbled across" my work online. He wrote: "I applaud you for your efforts in bringing an ancient yet still prevalent framework of the caste system under the microscope and opening it up to intellectual debate." He was born in Wolverhampton to "a Sikh (Tharkan)" socalled upper caste family. He was in love with a "Ravidassia (Chamar)," so-called "lower caste" Sikh girl a few years older than him. He writes that his devout Sikh upbringing had made him unaware of "subtle variances with the context of our religion." To him their "same skin color," "same native tongue," same food and "same stereotypical Indian experiences" were indistinguishable; she, however, was aware of "cultural subtleties." His father confronted him about his relationship early on and explained that it was "against family tradition," but a few years later came around to negotiate marriage arrangements. Her parents "had their reservations" but "gave the impression that they were open" to inter-caste marriage if his parents were. But because at every meeting "the tension was suffocating," the negotiations 
resulted in a dead-end. After this breakdown his parents did not want to re-approach her parents and she decided "it is best not to open up fresh wounds." He disclosed that in a "provoked reaction" he had told her father: "to keep his daughter." Yet, they met "sneakingly" for another year, during which he had attempted suicide several times. So as not to "exasperate their standpoint on her and her family" he did not share his suicidal tendencies with his parents. In the meantime, she resigned to "marry whoever her parents see fit." He wrote: "I would have stomached it if out of choice she did not want to be with me, but I cannot accept that we have to separate for the deranged reasoning imposed by the caste system!" He asked me to share his experience with "the greater community" so that it is "strong wake-up call." His piercing words were: "I would like to emphasize that it is not only those who belong to the lower tiers of caste segregation (or as you like to refer to them as SC) that suffer from the injustice. Whether you are viewed as an exclusive member of this bogus society, or whether you are considered as an untouchable, we are all victims!" Over a period of time, this email caused a shift in my perspective, expanding my understanding of the reach of caste.

On the day I received the email, I replied immediately but heard nothing back. Three months later an email from his sister arrived, thanking me for swiftly replying to her brother and informing me that tragically A. committed suicide within hours of writing to me. I was stunned. Literally. Even so, before I could tell his personal story, I needed to know the truth from the side of the woman he loved. Five years later, sometime in 2016, accidently I found an unopened text in messenger-a program I did not use in 2011-sent by the love of his life the day after he died. She wrote with knowledge of his email and supported his desire to share their story. Now the picture was as complete as it could be. The helplessness of a single individual confronting the unfathomable power of an "ancient" system relentlessly renewed, shouted out from the words in his email. I have named him this time, because despite having mentioned this tragedy in a publication (Dhanda 2017), some skeptical people wondered about its veracity. When I first shared the story in private conversations with deniers of caste at the EHRC stakeholder event in November 2013, they said I was being "too emotional." In the course of the last few years, I have heard many stories of painful obstructions, of traumatic experiences of shock, puzzlement, and sometimes recourse to a double life, while negotiating various avatars of the "caste system" reborn in Britain. The nature of caste consciousness in the UK is understudied. There are signs of the simulation of caste-blindness, which is in fact a refusal to acknowledge the pernicious aspects of caste practices. There is an avoidance in determining the reach of caste prejudice and the extent of caste discrimination.

NJ: This kind of human tragedy one encounters as scholars of caste indeed leaves deep marks and makes us more committed to playing our part in the struggle against the caste order as scholars. So, are these the circumstances in which you joined the anti-caste movement in the UK? Can you summarize your experience in the campaign for anti-caste legislation in the UK?

MD: Yes, it was impossible not to think of A.'s reaching out as tying me in to a permanent obligation. I had to devote myself to understanding the operations of this system that seemed to engulf and devour everything good and beautiful. The more I dug, the deeper and more widespread I found the systemic reach of caste. His words: "it is far too late for me..." haunt me. I decided to commit myself to dismantling "the 
deranged reasoning" of the caste order. In a way I had joined the anti-caste movement in 2008 , but after this tragic encounter it became a commitment for life.

Supporting the activism of Dalit groups came from sharing my research and joining the voices of those who were campaigning to bring caste under the purview of the UK's anti-discrimination legislation, the Equality Act 2010. There were community reports of caste discrimination, and discussions in public forums, radio, TV, conferences, springing from the prospect, and upshot, of the World Conference against Racism, Racial Discrimination, Xenophobia and Related Intolerance, held at Durban from August 31 to September 8, 2001. ${ }^{3}$ On April 23, 2013, the government passed the Enterprise and Regulatory Reform Act, sec 97 of which made the earlier "power" to add caste into a "duty." A law was passed that MPs "must" make caste an aspect of race in the Equality Act 2010. There was jubilation amongst the Buddhist, Ravidassia, Valmiki and other Dalit Punjabi groups with whom I had travelled to the momentous rally for lobbying MPs and Peers at the Houses of Parliament on that fine April day.

To assist the government in how this "duty" must be fulfilled, the UK Equality and Human Rights Commission (EHRC) was entrusted with the task of appointing a research team. In a competitive tender our project "Caste in Britain" (Sept. 20132014) was selected. As Principal Investigator, I led a consortium of 10 researchers from 5 universities with two Co-Investigators, Prof David Mosse (Anthropology, SOAS) and Dr. Annapurna Waughray (Law, Manchester Metropolitan University). The project involved extensive stakeholder engagement, because we wanted to have a genuine dialogue across differences. We were aware of the opposition to the legislation. Five organizations withdrew from participation a day before the stakeholders' workshop of 9 November 2013. ${ }^{4}$ Our EHRC report 92 (Dhanda, Mosse et al 2014) on the event describes the difficult process and names all the 60 invited organizations and over 50 invited experts on caste and discrimination. We made recommendations on how caste could most effectively be added to the Equality Act 2010 in EHRC report 91 (Dhanda, Waughray et al. 2014).

The next step for the government was to organize a public consultation, which was stalled due to pressure from various lobbyists of the anti-legislation side. When the Government Equalities Office (GEO) finally undertook the consultation in 2017 after much dithering on the part of the Conservative government-but, instead of following the mandate of the Parliament, the GEO succumbed to pressure from "upper-caste" lobbies, and changed the emphasis and scope of the question for the consultation. ${ }^{5}$ The result of this flawed consultation drawing 16,000+ responses was skewed and misrepresented. Consequently, the government announced in July 2018 that it had decided to "repeal" the duty, though it conceded that "guidance" on caste discrimination to all public bodies would be provided before the repeal. The GEO produced a draft of guidelines in 2019, "Caste and the Equality Act-what you need to know," on which we commented. The GEO acknowledged our contribution to the guidance in an email to me in February 2020, but has not yet issued these guidelinesapparently, it is waiting for ministerial approval. It is important to note that the process for the "repeal" of duty will only kick off when the guidance is published. The "duty" to add caste still stands and a primary legislation is required to enact the repeal of the duty. ${ }^{6}$ Therefore, it is not in the interest of pro-legislation stakeholders to push for the publication of the guidance. On the other hand, the anti-legislation 
stakeholders do not want any mention of caste anywhere in connection to antidiscrimination legislation or guidance, even though the guidance is non-statutory and does not impose legal obligations, nor is it an authoritative statement of the law. Whatever the ultimate trajectory of the legislation turns out to be, I am glad that we have contributed to the "guidance" on caste, which will be required whether or not the repeal of the "duty" to add caste is enforced.

\section{NJ: How did the UK's Hindu and Sikh organizations react to the single Equality Act?}

MD: Hindu and Jain organizations from the start were hostile to bringing caste under the purview of the single Equality Act. Hindu Council UK and Hindu Forum of Britain published reports in 2008 denying the existence of caste discrimination in Britain. Initially Sikh organizations accepted the fact of discrimination but gradually distanced themselves from the legal means proposed by pro-legislation groups. In fact, some Sikh organizations, e.g. the Sikh Federation UK, welcomed the UK government's decision in 2018 to repeal the duty to add caste to the Equality Act 2010. Barring a few exceptions, Sikh organizations seem to have heaved a sigh of relief that Sikhs will not be associated with casteism when the "duty" is repealed, because they had objections to the mention of "Sikh" in the definition of "caste" in the Explanatory Notes to the Equality Act. Thus, they have ended up supporting the Hindu groups who lobbied incessantly to derail the legislation. Sikhs seem to regard any "caste" talk as divisive of their dominant concern to mark themselves out as a separate "ethnic group." Further, Punjabis' memories of their caste-infused past and their imaginings of utopias are splintered. It has emerged that for many being castefree does not mean consciously overcoming prejudiced caste consciousness.

NJ: What about the recent (2020-2021) mobilization of UK Punjabis in favor of the farmers' demands? Could this signify a new phase of inter-caste unity between different Sikh caste groups in the UK?

MD: There is some potential there. Strikingly, the phenomenon of young Sikhs engaging with the caste question is a new development, accelerated by the recent Farmers' and Laborers' movement in India. ${ }^{7}$ In the online world, serious questions on caste are being asked. The activism of left-wing groups in Punjab like the Zameen Prapti Sangharsh Committee and the Kisan Mazdoor Sangharsh Committee which are cross-class and cross-caste alliances engaged in the protest has also been noticed by diaspora Punjabis. Young Sikhs in the diaspora have raised the question of caste and are inviting Indian activists to online platforms to reflect upon the problem of caste amongst Punjabis in a global sense. This is a little different from previous currents: I see new kinds of provocative anti-caste thinking taking shape, some inspired by renewed interest in the unfinished revolution of anti-casteism at the heart of Sikhi (a decolonized term for Sikhism), others making links between caste and racial capitalism. It is likely that social activism emerging from the university-educated generation of Dalit students and lecturers will give a new meaning to the anti-caste movement, beyond celebrations marking key events to embedding anti-caste thought in various university curriculuma in Western academia and interrogating caste in social life. The widespread support for Sikh-inspired energetic opposition to government-imposed farm laws favoring corporate interests, however, does not extend to the traditional supporters of the Modi regime. For example, the Hindu Forum of Britain defended the farm laws in a BBC Newsnight program (February 16, 2021). Ironically, these Modi bhaktas' (devotees of the Indian Prime Minister, Modi) 
usual harking to return to "sanatana" (eternal) civilizational values is accompanied by singing praises of "modernization" of agriculture even when it is destructive.

NJ: The anti-caste movement in the UK has a long history dating back to the 1960s. Did you personally meet the older generation of activists and what did you learn from them?

MD: Yes, I have met some of the older generation of activists. It was fascinating to hear about the journey of Bishan Dass Bains from the shop floor of Bilston Steel Works (1968) to Wolverhampton Mayor (1986). What I found most interesting was his experience with the Indian Workers Association (IWA), a Marxist organization which emerged in the West Midlands and consolidated as IWA (Great Britain) in 1958 (Dhanda 2013). It puzzled me that the IWA did not take up the question of caste. On learning about the direct conflict in the 1979 Wolverhampton council elections, when the IWA opposed Bishan Dass, things fell into place (Dass 2015). It was clear that the Communist vs Ambedkarite rivalries had a long history. Bishan Dass told me in a conversation that in a public meeting in the Civic Hall, Wolverhampton, he had gone on stage to say the "IWA is not Indian Workers Association, but a Jat Sabha." At the rally outside the Houses of Parliament in 2013, I had heard the slogans "down with Communism" from some Ambedkarites and this was a shock too. I argued with them, and fortunately there were activists like Satpal Muman who were more open to solidarity between the Left and Ambedkarites. In Wolverhampton in a small way I tried to bridge differences, urging some IWA members to discuss caste more openly.

NJ: How do you assess the future of caste in the UK and of the UK-based Dalit movement?

MD: I think the matter of inter-caste marriages will come to a head sooner or later. We know of individual families accepting transgressors of caste boundaries, but the collective view of maintaining endogamous choices is still very much the norm. There are no anti-caste initiatives openly to break the hold of caste endogamy as marriage is largely seen as a "private" matter not covered by the Equality Act around which UK Dalits have campaigned. But as educational establishments, through curriculum and public discussions, dig into the roots of the prevalence of caste prejudice in the diaspora, the "protection" of marriage choices from scrutiny will come under strain. In February 2020, Shaadi.com was accused of caste discrimination in using algorithms for match-making. I think scrutiny will have to emerge from Dalit youth in conversation with privileged caste groups. In the BBC1 documentary (dir. Qayum, October 13, 2019) we heard from a group of young people about the restriction faced by recent migrants from Daman to temple entry in Leicester, because of "low" caste status. So, tensions around caste re-emerge arising from the incorporation of fresh migrants in the settled community life of British South Asians where casteised socialization silently and habitually operates. These recurring assertions of caste privilege will need to be addressed by the movement.

NJ: Can you summarize your experience of anti-caste activism in the UK as an academic?

MD: Let me say at the outset: my experience is one of continuous learning. I have tried to change dominant perceptions of the "caste problem," leading to better understanding of divisions between stakeholder views, shaping and informing public attitudes through keeping a focus on caste in public debate. I have worked with campaigners to keep government accountable. In all of this, there are many difficult aspects of balancing the pursuit of "truth" through academic enquiry and positioning oneself to communicate findings with the world beyond academia. Anti-casteism is a matter of defending critical thinking from a moral standpoint which encourages 
internal critique of inherited traditions (Dhanda 2020a). I have experienced direct attack from the defenders of "tradition," including an academic, who dubbed my understanding of caste as a symptom of "colonial consciousness." We have debated in public forums. From 2013 onwards, I have been on Brit Asia TV and local Punjabi TV channels (Akaal, Lotus, Kanshi) and participated in BBC discussions on the nature of the caste problem in the UK. Some of us from the EHRC Caste in Britain team worked closely with the counsel for Ms. Tirkey, an exploited Adivasi Christian employee in the UK, whose case became precedent-setting in enabling caste discrimination to be addressed under existing provisions of the EA 2010 (Waughray and Dhanda 2016).

NJ: Other non-Dalit, mixed and white British academics like Annapurna Waughray and David Mosse supported and played a role in the mobilization to include caste in the Equality Act. However, what is your specific experience being a non-Dalit Indian? Were you easily accepted by the British Ambedkarite movement despite being a non-Dalit, and do you think it would have been the same in India?

MD: Annapurna is a pioneer in writing about the legal aspect of caste in UK law and David has long worked with DSN and Voice of Dalit International (VODI). David brought us together in a conference in 2012. As a non-Dalit Indian, having been brought up and educated in India, I had the advantage of trilingual access to the Punjabi diaspora. Ambedkarites knew that I had already introduced Ambedkar's thought to my university curriculum. I was invited by the Federation of Ambedkarite and Buddhist Organisations UK (FABO) to speak on Ambedkar at a public commemoration event at the All-Party Parliamentary Group (APPG) (Dalits) at the House of Lords. I recently asked Bishan Dass why he trusted me. He said it was due to my "stand on social philosophy," from my "bolna, chalna" (demeanor) when I visited the Buddha Vihara. There was no question mark about me, he said, and I showed "no orthodoxy." I sometimes ask my young interlocutors whether they can continue to trust me after knowing my non-Dalit birth status. This was acutely my concern in my research visits to India, where I interacted with many young Dalit scholars. I have been very fortunate in being allowed to join in conversations. Being "accepted" as a fellow traveler is all I expect. In the UK, I am a useful bridge between inhabitants of the caste world and bystanders, which I am not sure is needed in India. Here I have worked over a long and sustained period alongside activists, but in India I have engaged mainly as a researcher. I cannot speculate about whether I would be accepted as an activist. I do think though that anti-caste activism is everyone's responsibility, not just that of Dalits.

NJ: In your YouTube discussion on caste in the UK (Dhanda 2020b), you mention that although not being born a Dalit, you understand the term Dalit as a political term rather than a sociological category, which also connects to struggles against patriarchy. A number of non-Dalit women have joined the anti-caste movement. This was the case of the Maharashtrian, Brahmin scholar Sharmila Rege, the India-based American scholars Gail Omvedt and Eleanor Zelliot, Savita Ambedkar, Ambedkar's second wife, a Brahmin woman (although not everyone accepted her due to her caste background), and Savitri Bai Phule, who is today revered as the founding figure of Dalit feminism, although she belonged to a low caste but was not an "untouchable." Keeping all these examples in mind, how easy is it for a non-Dalit woman to join the anti-caste movement? While in India, Dalit feminism has been able to expand the basis of the anti-caste movement to non-Dalit feminists, do you 
see the potential for such alliances between South Asian women and the anti-caste movement in the diaspora?

MD: To join a movement is not difficult, but to bridge divides, negotiate factional differences and to keep the bigger picture in view-building a caste-free world-is hard work. One's birth status is not chosen, but our attitude towards it is chosen. Ultimately, it is not "facts" about origin that matter, rather one's actions determine if one is accepted with trust and mutual respect. I have luckily always felt accepted. Here's an example. In November 2019, at the Being Human festival of the Humanities, I organized a workshop, Overlooked Overlockers, with erstwhile women workers of the Midlands textile industry, attended by $50+$ women. I presented my Caste research, and they shared their stories-written down or related orally. In workshop discussions an underlying common thread of confrontation with patriarchy and racism united us, and alongside this caste oppression became an admissible third element. Just as anti-women and anti-Black prejudices were acknowledged as obstacles in migrant lives, similarly caste prejudice was acknowledged as a concern that had to be addressed. The key to some non-Dalit women being accepted, and others not, lies in commitment to ongoing interaction with people beyond the projects in which we participate with them. Another factor is facilitating a bridging role, becoming a conduit, and forming networks. For instance, in the UK, an alliance on anti-casteism between South Asia Solidarity Group and CasteWatch UK emerged when they met through our EHRC project in 2013.

NJ: The current debates on caste in India oppose a cultural view on caste as being mostly sustained by religious factors (Hinduism and its Brahmanical underpinnings), while Dalit Marxists like Teltumbde have sought to reintegrate caste as a defining feature of India's political economy. How, in your view, does the study of caste in the UK add to this debate? For instance, does the political and institutional context of Great Britain play a role in the reproduction of caste on British soil?

MD: This is a difficult question. We do not have a mapping of caste in the diaspora to say anything definitive about the political economy of caste. No one is interested in any census on caste in the UK, so we cannot map caste with class. We can estimate the political geography from party affiliations of supporters in the campaign for legislation which got the support of Jeremy Corbyn, who is a Trustee of Dalit Solidarity Network. Broadly, Labour supported the campaign in the Midlands. Matters have changed in the last few years, when the South Asian base of Labour has shifted to the Conservatives partly due to upward class mobility within the Sikh community, proudly noted by them in successive British Sikh Reports. Now caste status does seem to have aligned more with class status. In early migration, the dominant castes of South Asians were of the working-classes who have now become middle-class. Through this change some have also switched political loyalties to the Conservatives and have lost their left Labour leanings. Conservatism and denial of caste as a problem go together. The staunchest of opponents of the legislation, who speaks directly for the South Asian business lobby and has been a noted admirer of the PM of India since he was the CM of Gujarat, is Conservative MP Bob Blackman, who is also Chair of the All Party Parliamentary Group (Hindus).

I recall a meeting hosted by Ambedkarite activist Satpal Muman in 2013, which I attended as a silent observer. He asked a room full of about 70 people if there were any millionaires amongst them. There were none. Arguably Dalits who have broken the class ceiling by their individual effort, are unlikely to be present in the collective 
anti-caste movement. Broadly, I would say caste and class go together in the UK too, and Anand Teltumbde is right about the political economic determinants of caste. The economic determinations of caste status travel with migrants: privilege surfaces in the ease or difficulty migrants face in finding their feet in the host country, even as we allow for far more choices available to British citizens than to Indians to break out of ascribed status through professional upward mobility. The erasure of caste in social life is even more likely if they marry non-Asian Britishers. Endogamy continues to be restrictive and constrains social mixing and mobility. I have heard that the journey in some cases is dreadfully painful.

One aspect of caste that emerges in the UK, where racism is a fact of life, is that the ability to defy, challenge or overturn caste depends upon what I call the bystander effect-that is, the effect of the actions of third parties who are not directly a part of the caste world. This dynamic is not like that of the colonial encounter, as one may be tempted to assume. The bystander effect creates the possibility for deniers of caste discrimination to have recourse to an "emergent vulnerability" (Dhanda 2020a)-a victim reversal-whereby the so-called upper-castes claim to be "misrepresented." They are "hurt" by the calling out of the link between their cultural practices and caste discrimination. Someone must decide which side is correct-the accusers or the accused-in caste discriminatory practices. Caste discrimination moves out of the dyad of oppressor-oppressed into a triad of oppressor-spectator-oppressed, which makes the spectator into an adjudicator. Altercations have to be interpreted and accepted as genuine by clueless adjudicators, who claim ignorance and rely on noninterference as the best way forward for multicultural accommodation of "cultural difference."

NJ: The interplay between racism and casteism for South Asians seems to be quite intricate. Does the UK anti-caste movement take a position with regard to white racism? Are there connections being made with other forms of discriminations or are they considered separate topics?

MD: Yes indeed, these positionings go a long way back in British activists' lives. In the 70s, the Indian Workers Association spoke about the attack by white racists on Indians as attacks on Indian culture, but Bishan Dass called the Indian culture a "rotten culture," with caste and religious prejudice. He had fought racists as a young worker joining the Anti-Nazi League, with direct experience of defending Black workers against vigilante attacks. This is why I see a continuity in the experience of casteism faced by Dalits. For them, racism from the majority white community is continuous and comparable with casteism at the hands of the so-called upper-castes. However, the older generation feel caste humiliation more acutely than racism, due to a lingering identification as "migrants" and closeness to the "caste system" that they otherwise reject (Dhanda 2014). For the younger generation, racism hurts more than casteism, because of a greater sense of entitlement as British citizens, and lesser identification with the caste world. It is noteworthy that Satpal Muman ${ }^{8}$ had warned of a "backlash." Given the complexity in raising the matter of caste in a racist society, he worried that "conservative elements of the Indian community" would object to putting caste in the public domain and "right-wing fascists" might use divisions amongst Asians "as a weapon" to further their aims. Finally, anti-racist Asians may unfortunately see their work as "being undermined by our outcry against Caste" (Muman 2000). Since the institution of EA 2010, in the UK legal framework, "race" discrimination is the only available category for accommodating "caste" 
discrimination, and this too makes the interplay between racism and casteism central. I have argued in "Anti-casteism and Misplaced Nativism" (Dhanda 2015) that we have to focus on the lived experience of casteism and racism. Casteism, like racism, is not always reducible to intentions, as it is embedded in structural inequalities generating privileges for some and detriments for others. Happily, the younger generation is more confident in "facing prejudice" in the form of both casteism and racism (Dhanda 2014).

\section{BIBLIOGRAPHY}

Bains, Bishan Dass. 2015. Pride vs Prejudice. Jallandhar, India: Malin Prakashan.

Dhanda, Meena. 1993. "L'Éveil des intouchables en Inde." Pp. 130-45 in Le Respect. De l'estime à la déférence: une question de limite, edited by C. Audard. Paris: les Éditions Autrement.

Dhanda, Meena. 2008. The Negotiation of Personal Identity. Saarbrüken: Verlag Dr. Muller.

Dhanda, Meena. 2009. "Punjabi Dalit Youth: Social Dynamics of Transitions in Identity."

Contemporary South Asia 17(1):47-63.

Dhanda, Meena. 2012. “Runaway Marriages: A Silent Revolution?" Economic and Political Weekly XLVII(43):100-08.

Dhanda, Meena. 2013. "Caste and International Migration, India to the UK." In The Encyclopaedia of Global Human Migration (Four Volumes), editor-in-chief I. Ness. Oxford: Wiley Blackwell. doi: 10.1002/9781444351071.wbeghm105.

Dhanda, Meena. 2014. "Certain Allegiances, Uncertain Identities: The Fraught Struggles of Dalits in Britain.” Pp. 99-119 in Tracing the New Indian Diaspora, edited by O.P. Dwivedi. New York: Editions Rodopi.

Dhanda, Meena. 2015. "Anti-Castism and Misplaced Nativism: Mapping Caste as an Aspect of Race.” Radical Philosophy 192:33-43.

Dhanda, Meena. 2017. “Casteism Amongst Punjabis in Britain." Economic and Political Weekly LII(3): 62-65.

Dhanda, Meena. 2020a. "Philosophical Foundations of Anti-Casteism." Proceedings of the Aristotelian Society 120(1):71-96.

Dhanda, Meena. 2020b. “An Unnamable Injustice: The Caste Problem in the UK.” Practice of Caste in the USA: Discussion Series, Ambedkar King Study Circle (USA). Live August 8, 2020. Retrieved October 5, 2021 (https://www.youtube.com/watch?v=ikex5oH5ek\&list=PLcNyR-6AAKejc5JHYS3Z8h7nUBoUSnPoG\&index=16\&t=203s).

Dhanda, Meena, Annapurna Waughray, David Keane, David Mosse, Roger Green, and Stephen Whittle. 2014. Caste in Britain: Socio-legal Review. Equality and Human Rights Commission Research Report No. 91. Manchester: EHRC. Retrieved October 5, 2021 (https:// www.equalityhumanrights.com/sites/default/files/research-report-91-caste-in-britain-sociolegal-review.pdf). 
Dhanda, Meena, David Mosse, Annapurna Waughray, David Keane, Roger Green, Stephen Iafrati, and Jessie Kate Mundy. 2014. Caste in Britain: Experts' Seminar and Stakeholders' Workshop. Equality and Human Rights Commission Research Report no. 92. Manchester: EHRC. Retrieved October 5, 2021 (https://www.equalityhumanrights.com/sites/default/files/research-report-92-caste-inbritain-experts-seminar-and-stakeholders-workshop.pdf).

Garalyté, Kristina and Jean Thomas Martelli, eds. 2019. Student Politics in South Asia. SAMAJ 22. doi: 10.4000/samaj.5852.

Government Equalities Office (GEO). 2017. Caste in Great Britain and Equality Law: A Public Consultation. Retrieved October 5, 2021 (https://assets.publishing.service.gov.uk/government/ uploads/system/uploads/attachment_data/file/609641/170419_-_Caste_condoc_-_Final.pdf).

Hepple, Bob. 2010. “The New Single Equality Act in Britain.” The Equal Rights Review 5:11-24. Retrieved October 5, 2021 (https://www.equalrightstrust.org/ertdocumentbank/ bob\%20hepple.pdf).

Qayum, Farah, dir. 2019. Hindus: Do We Have a Caste Problem? BBC1 documentary, October 13. Jaoul, Nicolas. 2006. “L’Engagement des émigrés dalits. Idéologie et formation d'une conscience de diaspora." Diasporas. Histoire et sociétés 9:222-40.

Jaoul, Nicolas. 2021. "Beyond Diaspora: Ambedkarism, Multiculturalism and Caste in the UK." SAMAJ 27. Retrieved November 23, 2021 (https://journals.openedition.org/samaj/7489).

Joshi, Barbara, ed. 1986. Untouchable! Voices of the Dalit Liberation Movement. New Delhi: Zed Books. Juergensmeyer, Mark. 1991. Radhasoami Reality: The Logic of a Modern Faith. New Jersey: Princeton University Press.

Mogul, Priyanka, dir. 2017. Caste Aside. Independent documentary.

Muman, Satpal. 2000. "Caste in Britain." Dalit Human Rights, Report of the proceedings of an International Conference, London, September 16-17, organized by Voice of Dalit International (VODI) and Dalit Solidarity Network, published by VODI.

Singh, Tanya, P. Singh and Meena Dhanda. 2021. "Resisting a 'Digital Green Revolution': Agrilogistics, India's New Farm Laws and the Regional Politics of Protest." Editorial. Capitalism Nature Socialism 32(2):1-21. https://doi.org/10.1080/10455752.2021.1936917.

Waughray, Annapurna and Meena Dhanda. 2016. "Ensuring Protection against Caste Discrimination in Britain: Should the Equality Act 2010 be extended?" International Journal of Discrimination and The Law 16:177-19.

\section{NOTES}

1. The founder of the Radhasoami faith, Swami Shiv Dayal Singh, the son of a money lender born of Khatri caste in Agra, had "disdain for caste." After his death in 1878, the Radhasoami bifurcated into several branches. In Agra, the Dayalbagh "colony" of Radhasoamis was set up in 1915 by the third guru, Anand Swarup, an urban Punjabi of Ahluwalia caste, ex-member and opponent of the Arya Samaj. Like Ambedkar he was invited to speak by the Jat Pat Todak Mandal in Lahore in 1931. He was succeeded in 1937 by Gurcharandas Mehta, a Khatri, with whom my paternal grandparents enjoyed closeness and whom I met as a child a few times. See Juergensmeyer (1991).

2. On student politics in South Asia, see SAMAJ's special issue (Garalyté and Martelli 2019). 
3. CasteWatch UK came into being in 2003 under the leadership of Satpal Muman; Dalit Solidarity Network (DSN) published its report "No Escape" in 2006. Meena Varma (Director, DSN) actively lobbied civil servants to have caste included when the Discrimination Law review (2006) and Equalities Law review (2007) took place. Dr Annapurna Waughray (Law, Manchester Metropolitan University) supported her. In collaboration with Dr Roger Green and Prof Stephen Whittle, "Hidden Apartheid: Voice of the Community," a scoping study was published by the Anti-Caste Discrimination Alliance (2009) led by Santosh Dass. Finally, a government funded report, Caste Discrimination and Harassment in Great Britain (National Institute of Economic and Social Research, 2010) was a crucial contribution, but the campaign to add caste to the Equality Act succeeded only partially. When the Equality Act was instituted in April 2010, the inclusion of section 9(5)(a) in it gave a power for caste to be added in the future, by secondary legislation, to section 9(1) of the Act as "an aspect of" the protected characteristic of race, defined in the legislation as including color, nationality, and ethnic or national origins. (Dhanda, Waughray et al. 2014:1-3). See Hepple (2010) for the legal history of the development of the Equality Act 2010, noting that "caste may be added later by secondary legislation" (p. 16).

4. In the opening session of the stakeholders' workshop, the sole representative of the Sikh Council spent a lot of time expressing concern about those who had "pulled out" (e.g. the British Hindu Voice), questioning whether the discussion could proceed without them. Ironically, it was a Punjabi representative of the Hindu Lawyers Association who argued that if one wants to take part one ought to be present. He asked people to listen to the EHRC team and get on with the task at hand.

5. Instead of asking how caste must be added to the Equality Act 2010, the consultation took a backward step and asked whether caste must be added at all, suggesting strongly that developing case law was sufficient to cover caste discrimination and that it may not be necessary to act on the "duty" to add caste to the Equality Act (GEO 2017).

6. GEO 2017 (fn. 6, p. 8) clearly states: "Implementation of the duty would be by an affirmative order,-a type of secondary legislation which is debated by both Houses of Parliament and which either House can pass or reject but not amend. Repeal of the duty would be by primary legislation -an Act of Parliament."

7. See Singh, Tanya, Singh, Dhanda (2021) for a reflective comprehensive analysis of this movement.

8. Greater detail about Satpal Muman is included in Jaoul's article in this issue.

INDEX

Keywords: Ambedkar, UK, Punjab, Equality Act 2010, caste, diaspora

\section{AUTHORS}

NICOLAS JAOUL

CNRS, IRIS 
MEENA DHANDA

University of Wolverhampton 